\title{
Genç kadınların perspektifinden cinsel sağlık ve üreme sağlığında damgalama
}

\section{Stigmatization in sexual health and reproductive health from the perspective of young women}

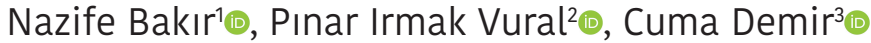

\section{öz}

AMAÇ: Bu çalışma genç kadınların cinsel sağlık ve üreme sağlığında damgalama düzeylerini belirlemek amacıyla yapılmıştır.

GEREC ve YÖNTEMLER: Bu araştırma Akdeniz bölgesinde bir ildeki 4 halk eğitim merkezinde 18-24 yaşları arasındaki kadın kursiyerlerle Eylül 2020-Aralık 2020 tarihlerinde yürütülmüştür. Araştırmanın verileri kadınların sosyo-demografik özellikler formu ve genç kadınlarda cinsel sağlığı ve üreme sağlığı damgalama ölçeği (GKCỨSDÖ) ile toplanmıştır.

BULGULAR: Çalışmaya katılan kadınların \%83,6'nın herhangi bir işte çalışmadığı, \%45,0'nın ilde yaşadığı, \%73,6'nın gelirin gidere eşit olduğu ve \%95,7'nin medeni durumunun bekar olduğu saptanmıştır. Yine herhangi bir işte çalışan katılımcıların GKCSÜSDÖ gerçek olmayan damgalama alt boyutu puan ortalamasının herhangi bir işte çalışmayan katılımciların puan ortalamalarından istatiksel olarak anlamlı düzeyde yüksek olduğu saptanmıştır. Köy-kasabada yaşayan katılımcıların GKCSÜSDÖ içsel damgalama alt boyutu puan ortalamasının şehir ve ilçede yaşayan katılımcıların puan ortalamalarından istatiksel olarak anlamlı düzeyde yüksek olduğu belirlenmiştir. Çalışmaya katılan genç kadınların anne eğitim durumunun ilköğretim ve ortaöğretim olan katılımcıların GKCSÜSDÖ dışsal damgalama alt boyutu puan ortalamasının eğitim durumu yükseköğretim olan katılımcıların puan ortalamalarından istatistiksel olarak anlamlı düzeyde yüksek olduğu saptanmıştır. SONUÇ: GKCSÜSDÖ alt boyutu olan dişsal damgalama puan ortalamasının 3,97 $\pm 1,82$ olduğu, gerçek olmayan damgalama alt boyutu puan ortalamasının $1,71 \pm 1,81$ olduğu, içsel damgalama alt boyutu puan ortalamasının $2,57 \pm 1,59$ olduğu ve ölçeğin toplamından alınan puan ortalamasının $8,26 \pm 3,84$ olduğu belirlenmiştir. Sonuç olarak genç kadınların GKCÜSDÖ toplam puan ortalamasının orta seviyenin altında olduğu saptanmıştır.

Anahtar Kelimeler: kadın, cinsel sağlık, üreme sağlığı, damgalama
${ }^{1}$ Burdur Mehmet Akif Ersoy Üniversitesi, Bucak Sağlık Yüksekokulu, Burdur, Türkiye ${ }^{2}$ İstanbul Medipol Üniversitesi, Sağlık Bilimleri Fakültesi, Hemşirelik Bölümü, i̇stanbul, Türkiye

${ }^{3}$ Fırat Üniversitesi Tıp Fakültesi Hastanesi, Elazığ, Türkiye

\section{Yazışma Adresi/ Correspondence:}

Dr. Öğr. Üyesi Nazife Bakır

Burdur Mehmet Akif Ersoy Üniversitesi, 15400 Burdur, Türkiye

Tel:

+905533997915

E-mail: nazbakir@hotmail.com

Gelis/ Received: $\quad 31.12 .2020$

Kabul/ Accepted: $\quad 09.02 .2021$

\section{ABSTRACT}

OBJECTIVE: The study was done in order to determine stigmatization level of young women in sexual health and reproductive health.

MATERIAL and METHODS: The study was undertaken with female course attendees aged 18-24 years at four public education centers in a city located in Mediterranean Region between September 2020 and December 2020. The study data were gathered using Socio-demographic Information Request Form for Women and Sexual and Reproductive Health Stigmatization Scale in Young Women (SRHSSYW).

RESULTS: It was identified that $83.6 \%$ of the participant women did not work anywhere, $45.0 \%$ of them resided in city centers, $73.6 \%$ of them had an income equal to expenses and $95.7 \%$ of them were single as marital status. It was found that average score of unreal stigmatization subscale of SRHSSYW was statistically and significantly higher among those who worked than those who did not work anywhere. It was identified that average score of internalized stigmatization subscale of SRHSSYW was statistically and significantly higher among those who resided in villages-towns than those who resided in cities and counties. It was seen that average score of external stigmatization subscale of SRHSSYW was statistically and significantly higher among those young participants whose mothers' educational status was primary school and secondary school than those whose mothers' educational status was higher education.

CONCLUSION: It was seen that average score of external stigmatization subscale of SRHSSYW was $3.97 \pm 1.82$, average score of unreal stigmatization subscale of SRHSSYW was $1.71 \pm 1.81$, average score of internalized stigmatization subscale of SRHSSYW was $2.57 \pm 1.59$ and average total score of SRHSSYW was $8.26 \pm 3.84$. As a result; it was seen that young women's total average score of SRHSSYW was below the average.

Keywords: women, sexual health, reproductive health, stigmatization

\section{Gíriș}

Cinsellik insan olmanın temel bir boyutu olarak ele alındığında, insan vücudu ile ilişkili bir anlamının olması ile birlikte, duygusal bağlanma, sevgi, seks, cinsiyet, cinsiyet kimliği, cinsel yönelim, cinsel yakınlık, haz ve üreme gibi kavramları barındırır. Cinsellik karmaşık bir süreç olmakla birlikte yaşam boyunca gelişen biyolojik, sosyal, psikolojik, manevi, dini, politik, yasal, tarihi, etik ve kültürel boyutları da içerir. ${ }^{[1]}$ 
Insan cinselliği, psikolojik, biyolojik, ilişkisel ve sosyokültürel belirleyicilerin entegrasyonuna bağlı olarak çok faktörlüdür. [2] Cinsel sağglık ve üreme sağlığı (CSÜS) kavramı literatürde çoğu kez birbirinin yerine kullanılsa da cinsel sağlık, üreme sağlığının bir parçası gibi de ele alınmaktadır. Dünya Sağlık Örgütü'ne göre cinsel sağlık, sadece hastalık, fonksiyon bozukluğu veya sakatlığın olmayışı değil, psikolojik, zihinsel ve sosyal olarak cinsellikle ilgili tam bir iyilik halinin olması durumudur. Cinsel sağlık, zorlama, ayrımcilık ve şiddetten uzak, zevkli ve güvenli bir cinsel deneyim ile birlikte cinselliğe ve cinsel ilişkiye olumlu ve saygılı bir yaklaşımı savunur. ${ }^{[2-4]}$ Kişilerin cinsellik ile ilgili duygu ve davranışlara, cinselliği ayrımcılık, zorlama, şiddetten uzak, güvenli ve keyifli bir şekilde sürdürmesi ve cinsel ilişkilere olumlu yaklaşması için cinsel haklarının korunması önem teşkil etmektedir. ${ }^{[5]}$

Üreme sağlığı (ÜS), intrauterin hayattan başlayarak yaşam boyu ele alınması gereken bir konudur. Özellikle adölesan ve gençlik dönemi, istenmeyen gebelikler, yasal olmayan düşükler, düşük komplikasyonları, cinsel yolla bulaşan enfeksiyonların (CYBE) artması, şiddet, cinsel tacizler gibi sorunlar ve adölesan evlilikler nedeniyle ÜS sorunları açısından riskli bir dönem olarak belirtilmektedir. ${ }^{[6]}$ Ayrıca ÜS kavramı, üreme sisteminin sağlığını belirttiği kadar, bireylerin tatmin edici ve güvenli bir cinsel yaşamlarının olmasını, üreme yeteneğini ve üreme yeteneklerini özgürce kullanabilme haklarını savunur. ${ }^{[5]}$

Gençlerin CSÜS ile ilgili davranışlarını ve bu davranışların sonuçlarını (gebelik, küretaj, CYBE, cinsiyet değişikliği gibi) ahlaksız ve sorunlu olarak gösteren sosyal, kültürel ve dini normlar, gençlerin damgalanmasına sebep olabilmektedir. ${ }^{[7]}$ Damgalama, insan farklılığını bir sosyal kontrol biçimi olarak etiketleme, basmakalıp değerlendirme ve reddetme sürecidir. ${ }^{[8]}$ Aynı zamanda kişilere karşı olumsuz tavırlar ortaya çıkaran bir utanç işaretidir. Damgalama; algılanan damgalama, kendini damgalama ve canlandırılmış damgalama gibi farklı kategorilerde ele alınmaktadır. [9] Damgalanma insan hayatında yıkıcı ve duygusal durumlara sebep olabilir. Örneğin CYBE’lar için, fiziksel ağrı düzeyi hafiftir ve tedavi başladığında oldukça hızlı bir şekilde ağrı düzeyi azalır. Fakat CYBE'ye bağlı olarak yapılan damgalanmanın oluşturduğu duygusal acılar ve bireyin hayatının geriye kalan kısmında bununla başetme zorunda olması daha yıkıcı olabilir. Cinsel yaşamın sağlıklı bir şekilde sürdürülmesi için, ayrımcıllk ve şiddetten uzak olarak cinselliğin yaşanabilmesi gerekir. Son yıllarda cinsel yönelim ve cinsel seçimleri farklı olan gençlerde madde bağımlılığı ve intiharlar gibi problemler daha sık yaşandı$\breve{g}_{1}$ görülmektedir. Bu durum toplum tarafından yapılan damgalamalar, gencin okulda, evde veya diğer sosyal ortamlarında deneyimlediği tacizler, fiziksel ve cinsel şiddet durumu ile ilişkilendirildiği belirtilmiştir. ${ }^{[7]}$ Damgalama nedeniyle kadınlar temel insan haklarının ihlali, toplum tarafından ayrımcılık ve dışlama sonucu damgalanmaya karşı daha fazla mücadele etmek zorunda kalmaktadır. Bu çalışma genç kadınların bakış açısıyla cinsel sağlık ve üreme sağlığında damgalama tutumlarını belirlemek amacıyla yapılmıştır.

\section{GEREÇ ve YÖNTEMLER}

\section{Araștırmanın Yapıldığı Yer ve Zaman}

$\mathrm{Bu}$ araştırma Akdeniz bölgesinde bir ildeki 4 halk eğitim merkezinde 18-24 yaşları arasındaki genç kadın kursiyerlerle Eylül 2020 - Aralık 2020 tarihlerinde yürütülmüştür.

\section{Veri Toplama Araçları}

Araştırmanın verileri sosyo-demografik özellikler formu ve genç kadınlarda cinsel sağlığı ve üreme sağlığı damgalama ölçeği (GKCÜSDÖ) ile toplandı.

Tanımlayıcı özellikler formu; katılımciların sosyo-demografik özelliklerini incelemeyi sağlayan 6 sorudan oluşmaktadır.

"Genç Kadınlarda Cinsel Sağlık Üreme Sağlık Damgalama Ölçeği”" (GKCÜSDÖ); Hall ve ark. ${ }^{[10]}$ tarafindan $15-24$ yaşındaki kadınlarda cinsel ve üreme sağlığına yönelik damgalamayı belirlemek için 2017 yılında geliştirilmiş olan ölçeğin Türkçe geçerlilik güvenirliği Bayrakçeken tarafından 2018 yılında yapılmıştır. ${ }^{[7]}$ GKCÜSDÖ’nün 3 faktörlü yapısını; 1., 2., 3., 4., 5., 6. maddeleri dişsal damgalama, 7., 8., 9., 10., 14., 15., 16, 19. ve 20. maddeleri gerçek olmayan damgalama, 11., 12., 13., 17. ve 18. maddeleri de içsel damgalama oluşturmaktadır. Ölçekten alınabilecek en düşük puan " 0 ”, en yüksek puan " 20 ”dir. Ölçeğin maddeleri " $0=$ Katılmıyorum, $0=$ Nötr, $1=$ Katılıyorum” şeklinde puanlanmıştır. Ölçekten alınan puan arttırkça damgalama tutumu artmaktadır. Türkçe geçerlilik güvenirliğinin yapıldığı çalışmada Cronbach alfa katsayısı 0,83 olup, ${ }^{[7]}$ bu çalışmada Cronbach alfa katsayısı 0,72 olarak hesaplanmışırı.

\section{Verilerin Toplanması}

$\mathrm{Bu}$ araştırma Akdeniz bölgesinde bir ildeki 4 halk eğitim merkezinde 18-24 yaşları arasındaki kursiyerlerinde Eylül 2020 - Aralık 2020 tarihlerinde yürütülmüsstür. Araştırmaya katılmayı kabul eden katılımcılara mobil/internet ağ sistemi ile google forms anket yöntemi kullanılarak anketler ulaştııılmıştır. Verilerin toplanması her bir katılımcının yaklaşık 10-15 dakika zamanını almıştır. 


\section{İstatistiksel Analiz}

Araştırmada elde edilen veriler SPSS 20.0 paket programı ile değerlendirilmiş olup, yüzde, frekans ile verilerin normal dağılıp dağılmadığını öğrenmek için Shapiro-Wilk testi yapılmıştır. Gruplar arası farklılıkların karşılaştırılmasında ANOVA, farklılığın anlamlılık derecesini tespit etmek için Bonferroni Post Hoc $t$ testi kullanılmıştır. İki grup arasında farklılığın karşılaştırılmasında Independent Samples T Test kullanılmıştır. $\mathrm{p}<0,05$ istatistiksel anlamlılık olarak kabul edilmiştir

\section{Etik}

Araştırmaya başlamadan önce İstanbul Medipol Üniversitesi Girişimsel Olmayan Klinik Araştırmalar Etik Kurulu onayı (Sayı: 10840098-772,02-E. 34282) alınmıştır. Araştırmaya katılan kadınlara araştırmanın amacı ile ilgili bilgi verilip elde edilen bilgilerin sadece bu araştırma için kullanılacağı, istedikleri zaman araştırmadan ayrılabilecekleri anketin önünde yer alan onam formunda belirtilmiştir.

\section{BULGULAR}

Çalışmaya katılan katılımcıların tanıtıcı özelliklere göre dağılımı tablo 1'de verilmiştir. Buna göre katılımcıların \%50,4'ü 18-20 yaşlarında, \%83,6'nın herhangi bir işte çalışmadığı, \%45,0'nın ilde yaşadığı, \%63,1'nin anne eğitim durumunun ilköğretim olduğu, \%45,0'nın baba eğitim durumunun ilköğretim olduğu, \%73,6'nın gelirin gidere eşit olduğu ve \%95,7'nin medeni durumunun bekar olduğu saptanmıştır (Tablo 1).

GKCSÜSDÖ alt boyutu olan dişsal damgalama puan or-

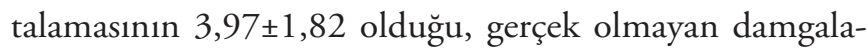
ma alt boyutu puan ortalamasının 1,71 $\pm 1,81$ olduğu, içsel damgalama alt boyutu puan ortalamasının $2,57 \pm 1,59$ olduğu ve ölçeğin toplamından alınan puan ortalamasının $8,26 \pm 3,84$ olduğu belirlenmiştir (Tablo 2).

Çalışmaya katılan katılımcıların cinsel üreme sağlığı damgalama ölçeğinin tanıtıcı özelliklerine göre dağılımı Tablo 3'de verilmiştir. Buna göre herhangi bir işte çalışan katılımcıların GKCSÜSDÖ gerçek olmayan damgalama alt boyutu puan ortalamasının herhangi bir işte çalışmayan katılımcıların puan ortalamalarından istatistiksel olarak anlamlı düzeyde yüksek olduğu saptanmıştır. Köy-kasabada yaşayan katılımcıların GKCSÜSDÖ içsel damgalama alt boyutu puan ortalamasının şehir ve ilçede yaşayan katılımcıların puan ortalamalarından istatistiksel olarak anlamlı düzeyde yüksek olduğu belirlenmiştir. Yine köy-kasabada yaşayan katılımcıların GKCSÜSDÖ
Tablo 1. Katılımcıların tanıtıcı özelliklere göre dağılımı

\begin{tabular}{|c|c|c|}
\hline Tanıtıcı Özellikler (n=371) & $N$ & $\%$ \\
\hline \multicolumn{3}{|l|}{ Yaş } \\
\hline $18-20$ & 187 & 50,4 \\
\hline $21-24$ & 184 & 49,6 \\
\hline \multicolumn{3}{|l|}{ Çalışma Durumu } \\
\hline Evet & 61 & 16,4 \\
\hline Hayır & 310 & 83,6 \\
\hline \multicolumn{3}{|l|}{ Yaşadığı Yer } \\
\hline il & 167 & 45,0 \\
\hline İlçe & 126 & 34,0 \\
\hline Köy-Kasaba & 78 & 21,0 \\
\hline \multicolumn{3}{|l|}{ Anne Eğitim Durumu } \\
\hline İlköğretim & 234 & 63,1 \\
\hline Ortaöğretim & 112 & 30,2 \\
\hline Yükseköğretim & 25 & 6,7 \\
\hline \multicolumn{3}{|l|}{ Baba Eğitim Durumu } \\
\hline İlköğretim & 167 & 45,0 \\
\hline Ortaöğretim & 146 & 39,4 \\
\hline Yükseköğretim & 58 & 15,6 \\
\hline \multicolumn{3}{|l|}{ Ekonomik Durum } \\
\hline Gelir Giderden İyi & 52 & 14,0 \\
\hline Gelir Gidere Eşit & 273 & 73,6 \\
\hline Gelir Giderden Düşük & 46 & 12,4 \\
\hline \multicolumn{3}{|l|}{ Medeni Durum } \\
\hline Evli & 16 & 4,3 \\
\hline Bekar & 355 & 95,7 \\
\hline TOPLAM & 371 & 100 \\
\hline
\end{tabular}

Tablo 2. GKCSÜSDÖ’nün alt boyutlarına ait maddeler ve ölçek toplam puan ortalamaları

\begin{tabular}{lc}
\hline GKCÜSDÖ Alt Boyutları & $\bar{X} \pm$ SS (Min-Max) \\
\hline Dışsal Damgalama & $3,97 \pm 1,82(0-6)$ \\
Gerçek Olmayan Damgalama & $1,71 \pm 1,81(0-9)$ \\
İçsel Damgalama & $2,57 \pm 1,59(0-5)$ \\
GKCÜSDÖ Toplam & $8,26 \pm 3,84(0-20)$ \\
\hline
\end{tabular}

toplam puan ortalamalarının şehir ve ilçede yaşayan katılımcıların puan ortalamalarından istatistiksel olarak anlamlı düzeyde yüksek olduğu saptanmıştır. Çalışmaya katılan genç kadınların anne eğitim durumunun ilköğretim ve ortaöğretim olan katılımcıların GKCSÜSDÖ dışsal damgalama alt boyutu puan ortalamasının eğitim durumu yükseköğretim olan katılımcıların puan ortalamalarından istatistiksel olarak anlamlı düzeyde yüksek olduğu saptanmıştır. Aile gelir durumu orta ve kötü olan 
Tablo 3. Katılımcıların GKCSÜSDÖ puan ortalamalarının tanıtıcı özelliklerine göre dağılımı

\begin{tabular}{|c|c|c|c|c|c|}
\hline Tanıticı özellikler & & $\begin{array}{c}\text { Dişsal } \\
\text { Damgalama }\end{array}$ & $\begin{array}{c}\text { Gerçek Olmayan } \\
\text { Damgalama }\end{array}$ & $\begin{array}{c}\text { İcsel } \\
\text { Damgalama }\end{array}$ & Toplam \\
\hline & $18-20$ & $4,10 \pm 1,80$ & $1,62 \pm 1,73$ & $2,57 \pm 1,57$ & $8,29 \pm 3,73$ \\
\hline \multirow[t]{3}{*}{ Yaş** } & $21-24$ & $3,84 \pm 1,83$ & $1,80 \pm 1,88$ & $2,58 \pm 1,62$ & $8,23 \pm 3,96$ \\
\hline & Test istatistiği & 0,798 & 0,653 & 0,044 & 0,292 \\
\hline & $\mathrm{p}$ & 0,180 & 0,315 & 0,981 & 0,880 \\
\hline \multirow[t]{4}{*}{ Çalışma Durumu** } & Evet & $3,85 \pm 1,89$ & $2,26 \pm 2,17$ & $2,42 \pm 1,60$ & $8,54 \pm 4,14$ \\
\hline & Hayır & $4,00 \pm 1,80$ & $1,60 \pm 1,71$ & $2,60 \pm 1,59$ & $8,21 \pm 3,78$ \\
\hline & Test istatistiği & 0,415 & 4,482 & 0,017 & 0,001 \\
\hline & $\mathrm{p}$ & 0,577 & 0,029 & 0,417 & 0,574 \\
\hline \multirow[t]{5}{*}{ Yaşadığı Yer* } & İl a & $3,82 \pm 1,96$ & $1,55 \pm 1,69$ & $2,41 \pm 1,42$ & $7,79 \pm 3,77$ \\
\hline & İlçe b & $4,02 \pm 1,65$ & $1,66 \pm 1,77$ & $2,49 \pm 1,71$ & $8,18 \pm 3,83$ \\
\hline & Köy-Kasaba c & $4,21 \pm 1,74$ & $2,14 \pm 2,04$ & $3,07 \pm 1,66$ & $9,43 \pm 3,82$ \\
\hline & Test istatistiği & 1,296 & 2,918 & 4,990 & 5,018 \\
\hline & $\mathrm{p}$ & 0,275 & 0,055 & $0,007(c>a, b)$ & $0,007(c>a, b)$ \\
\hline \multirow[t]{5}{*}{ Anne Eğitim Durumu* } & Illköğretim a & $3,98 \pm 1,72$ & $1,65 \pm 1,74$ & $2,72 \pm 1,59$ & $8,37 \pm 3,69$ \\
\hline & Ortaöğretim b & $4,21 \pm 1,80$ & $1,64 \pm 1,70$ & $2,34 \pm 1,56$ & $8,20 \pm 3,77$ \\
\hline & Yükseköğretim c & $2,80 \pm 2,36$ & $2,56 \pm 2,63$ & $2,24 \pm 1,66$ & $7,60 \pm 5,40$ \\
\hline & Test istatistiği & 6,345 & 2,956 & 2,760 & 0,475 \\
\hline & $p$ & $0,002(a, b>c)$ & 0,054 & 0,065 & 0,622 \\
\hline \multirow[t]{5}{*}{ Baba Eğitim Durumu* } & İlköğretim & $4,11 \pm 1,62$ & $1,66 \pm 1,71$ & $2,73 \pm 1,56$ & $8,52 \pm 3,65$ \\
\hline & Ortaöğretim & $3,95 \pm 1,90$ & $1,58 \pm 1,65$ & $2,47 \pm 1,58$ & $8,01 \pm 3,77$ \\
\hline & Yükseköğretim & $3,62 \pm 2,11$ & $2,17 \pm 2,34$ & $2,39 \pm 1,69$ & $8,18 \pm 4,54$ \\
\hline & Test istatistiği & 1,640 & 2,283 & 1,521 & 0,691 \\
\hline & $\mathrm{p}$ & 0,195 & 0,103 & 0,220 & 0,502 \\
\hline \multirow[t]{5}{*}{ Ekonomik Durum* } & Gelir Giderden İyi a & $3,44 \pm 2,06$ & $1,63 \pm 1,64$ & $2,07 \pm 1,51$ & $7,15 \pm 3,81$ \\
\hline & Gelir Gidere Eşit b & $4,08 \pm 1,75$ & $1,66 \pm 1,71$ & $2,61 \pm 1,62$ & $8,36 \pm 3,75$ \\
\hline & Gelir Giderden Düşük c & $3,93 \pm 1,87$ & $2,08 \pm 2,42$ & $2,93 \pm 1,42$ & $8,95 \pm 4,24$ \\
\hline & Test istatistiği & 2,749 & 1,119 & 3,845 & 3,039 \\
\hline & $\mathrm{p}$ & 0,065 & 0,328 & $0,022(c, b>a)$ & $0,048(c, b>a)$ \\
\hline \multirow[t]{4}{*}{ Medeni Durum** } & Evli & $3,18 \pm 2,34$ & $2,56 \pm 2,47$ & $2,43 \pm 1,63$ & $8,18 \pm 4,83$ \\
\hline & Bekar & $4,01 \pm 1,79$ & $1,67 \pm 1,77$ & $2,58 \pm 1,59$ & $8,27 \pm 3,80$ \\
\hline & Test istatistiği & 5,233 & 3,292 & 0,014 & 0,838 \\
\hline & $p$ & 0,185 & 0,176 & 0,726 & 0,945 \\
\hline
\end{tabular}

* One-Way ANOVA.

** Indenpendent Samples t-test.

katılımcıların GKCSÜSDÖ toplam ve içsel damgalama alt boyutu puan ortalamasının aile gelir durumu iyi olan katılımciların puan ortalamasından istatistiksel olarak anlamlı düzeyde yüksek olduğu saptanmıştır (Tablo 3).

\section{TARTIȘMA}

Bu çalışma genç kadınların perspektifiniden cinsel sağlık ve üreme sağlığında damgalama tutumlarını belirlemek amacıyla yapılmıştır. Bu çalışmaya katılan kadınların damgalama tutum düzeyinin orta seviyenin altında olduğu belirlenmiştir. Ölçeğin geçerlik güvenirliğinin yapıldığı

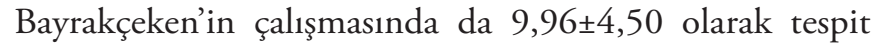
edilmiştir ve bu çalışmayla benzer düzeyde olduğu saptanmıştır. ${ }^{[7]}$ Çalışmaya katılan köy ve kasabada yaşayan ve ekonomik gelir düzeyi giderden düşük olan kadınların içsel damgalama alt boyutu ve toplam ölçek puan ortalamasının daha yüksek olduğu ve istatistiksel açıdan anlamlı düzeyde farklı olduğu ortaya çıkarılmıştır. İçselleştirilmiş damgalama veya öz damgalama, genel olarak halkın inandığı tehlikeli ve yetersiz olma gibi damgalayıcı görüşlerin birey tarafından benimsenmiş olmasıdır. Bireyin toplumun 
olumsuz değerlendirmelerini kabul etmesi ve bunu kendi kişisel değer sistemi ve benlik algısı ile birleştirmesi içselleştirilmiş damgalamadır. ${ }^{[11]}$

Birey içinde bulunduğu toplumdaki negatif kalıp yargılarını kabullenir ve nihayetinde utanç, değersizlik gibi olumsuz duygularla kendini toplumdan geri çekme davranışı gösterir. Birey toplumdan, iş, evlilik, tedavi olma gibi yaşam haklarından kendini geri çeker, bu geri çekilme ve aynı zamanda içselleştirilmiş damgalamanın artışı ile bireyin benlik saygısı zarar görür, kendini sevmekten ve değerli görmekten yoksun bırakır. ${ }^{[12]} \mathrm{Bu}$ çalışmada düşük sosyokültürel düzeydeki kadınlarda cinsel sağlığa yönelik damgalamanın daha yüksek olduğu belirlenmiştir. Destekler nitelikte; Bilge ve Çam’ın belirttiğine göre düşük düzeyli sosyokültürel yapıya dâhil olmak damgalama tutumunu olumsuz etkilemektedir. Bunun yanında yüksek eğitim düzeyinin de damgalama tutumunu olumlu yönde etkilediğini bildirmişlerdir. ${ }^{[13]}$

Dışsal damgalama daha çok toplumsal normlarla ilişkilidir. Sosyal damga, toplumda oluşturulmuş bir yapıdır ve damgalanmış kişilere karşı bariyer oluşturmaktır. Bu yapı içindeki damgalanmış birey, toplumda daha alt gruba ve daha az eşit bir konuma konularak eşitsiz bir dağılıma yol açmaktadır. ${ }^{[13]} \mathrm{Bu}$ çalışmaya katılan kadınların anne eğitim düzeyleri ilköğretim düzeyinde olanların dışsal damgalama alt boyutu ile istatistiksel olarak anlamlı düzeyde farklı ve yüksek olduğu belirlenmiştir, ayrıca baba eğitim düzeyi yükseldikçe damgalama puan ortalamaları da düşmektedir (Tablo 3). GKCSÜSDÖ dişsal damgalama alt boyutunda cinsel ilişki yaşama, küretaj, aile planlaması yöntemleri, genç yaşta hamile kalma ile ilişkili ifadeler yer almaktadır. Bu sonuçlar ışığında eğitim düzeyinin cinsel sağlık ve üreme sağlığına damgalamayı etkileyen sosyokültürel bir etmen olduğu ve düşük düzeyde anne ve baba eğitim düzeyinin genç kadınlarda cinsel sağlık ve üreme sağlığına yönelik damgalama düzeyini artırdığı düşünülmektedir.

Damganın temel unsurlardan bir tanesi “önyargıdır” ve kadınlara yönelik sosyal yaşam içerisindeki önyargılar, cinsel roller üzerinden değerlendirildiğinde, erkeklere göre daha fazladır. Kadınların üzerindeki ağır kalıp ve psikolojik yargılar kendi dinamiklerini yok etmesine sebep olmaktadır. Ataerkil bir toplum yapısında oluşturulmuş olan sosyal ve kamusal düzen kadını kendi istikametinde konumlandırdığı için bu sınıflamanın içerisine giremeyen kadınlar paralel olarak dışlanmaya maruz kalmaktadır. Örnek olarak; sigara içen kadın, kürtaj yaptıran kadın, araba kullanan kadın, çocuğu olmayan kadın, alımlı kadın, şişman kadın vb. birçok ifadede kadının erkeğe kıyasla sosyal çevrede çeşitli etiketlerle değerlendirildiği görülmektedir. ${ }^{[14]}$

Kadın sağlığında en çok damgalama sorunu yaşanan konular; küretaj ve gebelik sonlandırma, infertilite, AIDS ve
HIV taşıyıcıları, üriner inkontinans, CYBE ve paralı seks işçiliği olarak sıralanabilir. Kadınlar küretaj yaptırırken damgalanma riskiyle karşı karşıya kalır. Toplumda küretaj damgalaması, küretajın ahlaki olarak uygun olmayan ve sosyal olarak kabul edilemez olduğu konusunda ortak bir anlayış olarak karşımıza çıkmaktadır. ${ }^{[15]} \mathrm{Bu}$ çalışmada Dişsal Damgalama alt boyununun maddelerinden biri olan "İnsanlar küretaj yaptırdığını bildikleri bir gence fark1 davranırlar." ifadesinde de toplumsal damgalamaya dikkat çekilmiştir. Küretaj damgalanmasında, bireyin içinde yaşadığ1 toplumun küretaja yönelik görüş ve tutumu oldukça önemlidir. Bir sistematik derlemede; evlilik öncesi cinsel ilişkiye olumsuz bakılan toplumlarda, evlenmemiş kadınların küretaj deneyimlemesine daha olumsuz bakıldığ , bu kişilere ailesine bir utanç getiren, namus yoksunu, sadakatsiz, katil, kötü niyetli ve evlenilmesi uygun olmayan kişiler olarak bakıldığı görülmüştür. Kadınların, küretaj deneyimlerini paylaştıklarında diğer insanlar tarafından ayıplanmaktan veya damgalanmaktan çekindiklerinden, sosyal geri çekilme davranışı sergiledikleri, küretaj sebepli damgalanma endişesi taşıyan kadınlarda keder, anksiyete ve depresyon belirtileri de gözlendiği bulunmuştur. ${ }^{[15]}$

Cinsel sağlık ve üreme sağlığı damgalama tutmu konusunda literatürde çok sayıda CBYE ve farklı cinsel yönelimi olan bireylerde yapılan çalışmalar mevcuttur. Hastalıklarıyla damgalanmak, HIV (Human Immunodeficiency Virüs) pozitif insanlar için her zaman bir sorun olmuştur. ${ }^{[16]}$ Toplumda farklı cinsel yönelimi olan bireylerin de damgalama ile başetmesi oldukça zordur. Amerika'da yapılmış bir çalışmada farklı cinsel yönelimde özellikle biseksüel olan bireylerde depresyon ve damgalanma düzeylerinin oldukça yüksek olduğu belirlenmiştir. ${ }^{[17]}$ Başka bir çalışmada da gey, lezbiyen ve biseksüel bireylere yönelik homofobik ifadelerin, mülk hasarının, istihdam ayrımcılığı ve barınma ayrımcılı̆̆ının özellikle kırsal bölgede oldukça fazla olduğu bildirilmiştir. ${ }^{[18]}$ Geleneksel cinsiyet rollerine bağlı kalmayan gey ve lezbiyen insanlar, genellikle cinsiyet rolüne uygun olanlara göre daha fazla mağdur olmakta, ayrımcılığa maruz kalmaktadır ve damgalamayı içselleştirme olasılıkları daha fazladır. ${ }^{[19]}$ Farklı cinsel yönelimi olan bireyler toplumdan soyutlanmakta, onaylanmamakta, hatta küçümsenme ve aşağılanma endişesi içinde daha kaygılı ve depresif olarak kendi içlerinde, kendilerine özgü bir alt kültürü yaşamaya mahkûm bırakılmaktadır. $^{[20]}$ Kişilerin ya da grupların sahip olduğu ayırt edici özellikler ne olursa olsun, damgalama bireyleri, grupları başkalarının gözünde önemli ölçüde itibarsızlaştıran dinamik bir değer düşürme sürecidir. ${ }^{[21]}$

\section{SONUÇ}

Bu çalışmaya katılan köy-kasabada yaşayan genç kadınların GKCSÜSDÖ toplam puan ortalamalarının şehir ve ilçede 
yaşayan katılımcıların puan ortalamalarından istatistiksel olarak anlamlı düzeyde yüksek olarak belirlenmiştir. Aile gelir durumu orta ve kötü olan katılımcıların GKCSÜSDÖ toplam puan ortalamasının aile gelir durumu iyi olan katılımcıların puan ortalamasına göre istatistiksel olarak anlamlı düzeyde yüksek olduğu saptanmıştır. Bu çalışmada GKCÜSDÖ toplam puan ortalamasının orta seviyenin altında olması sevindirici bir sonuçtur, fakat sadece bir ilde yürütülmüş olması çalışmanın kısıtlayıcı yönüdür, literatüre kazandırılmış yeni bir ölçek olduğu için yapılmış başka bir çalışmaya rastlanamamıştır, ülkenin farklı bölgelerinde de benzer çalışmaların yürütülmesi önerilmektedir. Toplumun cinsel sağlık ve üreme sağlığı konusunda bilgilendirilmesi damga etkisini azaltacaktır. Bu nedenle eğitim programlarının planlanması ve damgalamayla mücadelede araştırma programlarının oluşturulması önerilmektedir. Damgalama ile mücadelede önceliklerden birisi bireylerin tutumlarının değiştirilmesidir, cinsel sağlık ve üreme sağlığı konularına olumsuz tutumlarını engellemede etkili olacağı düşünülerek eğitim programlarının ilköğretim düzeyinde başlamış olması önerilmektedir.

\section{Etik Kurul Onayı}

Çalışma, İstanbul Medipol Üniversitesi Girişimsel Olmayan Klinik Araştırmalar Etik Kurulu tarafından onaylandı. (onay tarihi ve sayısı: 07.08.2020/10840098-772,02-E. 34282).

\section{Hakem Değerlendirmesi}

Dış bağımsız.

\section{Çıkar Çatışması}

Yazarlar çıkar ilişkisi olmadığını beyan etmişlerdir.

\section{Finansal Destek}

Herhangi bir mali destek alınmamıştır.

\section{Ethics Committee Approva}

The study was approved by the Istanbul Medipol University Non-Invasive Clinical Research Ethics Committee. (date and number of approval: 07.08.2020/10840098-772,02-E. 34282).

\section{Peer-review}

Externally peer-reviewed.

\section{Conflict of Interest}

No conflict of interest was declared by the authors.

\section{Financial Disclosure}

No financial support has been received.

\section{KAYNAKLAR}

1. UNESCO. International Technical Guidance on Sexuality Education: An Evidence-Informed Approach for Schools, Teachers and Health Educators. Volume I and II; 2018. http://unesdoc. unesco.org/images/0026/002607/260770e.pdf

2. Scavello I, Maseroli E, Di Stasi V, Vignozzi L. Sexual health in menopause. Medicina (Kaunas) 2019;55:559. [CrossRef]

3. Marcell. AV, Burstein GR; Committee on adolescence. Sexual and Reproductive Health Care Services in the Pediatric Setting. Pediatrics 2017;140:e20172858. [CrossRef]

4. WHO. Sexual Health; 2018. http://www.who.int/topics/sexual_ health/en/

5. Koçak YD, Duman BN. Türkiye'de hemşirelik alanında üreme sağlığı-cinsel sağlık konularında yapılmış olan tezlerin içerik açısından incelenmesi. ACU Sağlık Bilimleri Derg 2019;10:26570. [CrossRef]
6. Duman BN, Yılmazel G, Topuz Ş, Başcı AB, Koçak YD, Büyükgönenç L. The knowledge, attitudes and behaviours of the university youth about reproduction health and sexual health. Yıldırım Beyazıt Üniversitesi Sağlık Bilimleri Fakültesi Hemşirelik E-Derg 2015;3:19-32. http://earsiv.hitit.edu.tr/xmlui/bitstream/ handle/11491/437/abb.pdf?sequence=2

7. Bayrakçeken E. Genç Kadınlarda Cinsel ve Üreme Sağlı̆̆ı Damgalama Ölçeği geçerlik ve güvenirliği. Atatürk Üniversitesi Sağlik Bilimleri Enstitüsü. Doğum, Kadın Sağlığı ve Hastalıkları Hemşireliği Ana Bilim Dalı Yüksek Lisans Tezi. Erzurum 2018. https://toad.halileksi.net/sites/default/files/pdf/cinsel-uremesagligi-damgalama-olcegi-toad.pdf

8. White Hughto JM, Reisner SL, Pachankis JE. Transgender stigma and health: A critical review of stigma determinants, mechanisms, and interventions. Soc Sci Med 2015;147:222-31. [CrossRef]

9. Mohammadi F, Kohan S, Mostafavi F, Gholami A. The Stigma of Reproductive Health Services Utilization by Unmarried Women. Iran Red Crescent Med J 2016;18:e24231. [CrossRef]

10. Hall KS, Manu A, Morhe E, Harris LH, Loll D, Ela E, et al. Development and Validation of a Scale to Measure Adolescent Sexual and Reproductive Health Stigma: Results From Young Women in Ghana. J Sex Res 2018;55:60-72. [CrossRef]

11. Çam O, Çuhadar D. Ruhsal hastalığa sahip bireylerde damgalama süreci ve içselleştirilmiş damgalama. Psikiyatri Hemşireliği Derg 2011;2:136-40. https://jag.journalagent.com/phd/pdfs/ PHD_2_3_136_140.pdf

12. Yakar C. Ruhsal hastalıklarda içselleştirilmiş damgalanma ve benlik saygısı üzerine bir meta analiz çalışması, Çağ Üniversitesi Sosyal Bilimler Enstitüsü Psikoloji Ana Bilim Dalı. Yüksek lisans dalı, Mersin; 2019. http://openaccess.cag.edu.tr/xmlui/ bitstream/handle/20.500.12507/1095/CANAN\%20YAKAR. pdf?sequence $=3$ \&isAllowed $=y$

13. Bilge A, Çam O. Ruhsal hastalığa yönelik damgalama ile mücadele. TAF Prev Med Bull 2010;9:71-8. https://www.bibliomed.org/ mnsfulltext/1/khb_009_01-71.pdf?1630240389

14. Sevim K. Sosyal çalışma perspektifinden damga ve kadın. Bingöl Üniversitesi Sosyal Bilimler Enstitüsü Derg (BUSBED) 2018;8:469-80. [CrossRef]

15. Yılmaz B, Şahin N. Kürtaj ve damgalanma: Bir sistematik derleme. Turkiye Klinikleri J Med Ethics 2020;28:451-62. [CrossRef]

16. Etik AD, Temel MK, Ertin H. HIV pozitif bireyin topluma entegrasyonu: Türkiye'de HIV/AIDS ve sosyoetik refleksiyonlar. Yeni Üroloji Derg 2013;8:50-4. https://dergipark.org.tr/tr/ download/article-file/1018092

17. Marsack J, Stephenson R. Sexuality-based stigma and depression among sexual minority individuals in rural United States. J Gay Lesb Ment Health 2017;21:51-63. [CrossRef]

18. Swank E, Frost DM, Fahs B. Rural location and exposure to minority stress among sexual minorities in the United States. Psychol Sex 2012;3:226-43. [CrossRef]

19. Salvati M, Pistella J, Baiocco R. Gender roles and internalized sexual stigma in gay and lesbian persons: A quadratic relation. Int J Sex Health 2018;30:42-8. [CrossRef]

20. Sevencan F, Aslan D, Akın A, Akın L. Seks çalışanı kadınlar, erkeklerle cinsel ilişkiye giren erkekler ve transseksüellerin toplumsal cinsiyet hakkındaki görüşleri. Türkiye Sosyal Araştırmalar Derg 2012;162. https://dergipark.org.tr/tr/pub/tsadergisi/issue/21489/230345

21. Zorlu M, Çalım Sİ. İşyerinde Damgalama ve Ayrımcılık Faktörü Olarak HIV/AIDS. Çalışma ve Toplum 2012;4:165-88. https:// calismatoplum.org/Content/pdf/calisma-toplum-1437-332229ae. pdf 